Det relationelle selv.

Om problematiseringen af

relationer i psykoanalysen

DPU - Danmarks institut for Paedagogik og

Uddannelse

Anders Drœby Sørensen

Monografi 
ISBN: 978-87-7507-355-9

DOI: 10.7146/aul.99.91 


\title{
Det relationelle selv. Om problematiseringen af relationer i psykoanalysen
}

\author{
Anders Drcby Sørensen
}

\section{Indledning}

I løbet af de seneste årtier har en lang række historikere, sociologer og kulturanalytikere været optaget af at påvise, hvordan vores nuværende idéer om selvet og de tilknyttede forestillinger om menneskelig identitet, autonomi, individualitet, frihed, valg og selvrealisering har en kompleks historisk, social og kulturel herkomst og derfor ikke kan påberåbe sig nogen status af universel gyldighed (se f.eks. Foucault (1992a+b); Porter (1997); Rose (1998); Martin (2006)). Samtidig er det fra disse historisk, socialt og kulturelt orienterede videnspositioner blevet gjort gældende, at det vestlige menneske gennem tidens løb har haft forskellige forestillinger og grundantagelser om sig selv med vidt forskelligt betydningsmæssigt indhold, der har været dybt afhængige af menneskets konkrete samfundsmæssige kontekst. At vores relation til os selv fundamentalt set afhænger af den sammenhæng vi lever i, betyder i denne horisont at videnskaben og filosofien heller ikke på nogen måde kan finde frem til en essentiel og transhistorisk subjektivitet hinsides vores kontekstbundne erfaringer af os selv. Sådanne aktuelle socialkonstruktivistiske bestræbelser på at forstå selvet som helt igennem et historisk og sociokulturelt fænomen skal for det første ses på baggrund af, at selvet i det hele taget er blevet genstand for større og større opmærksomhed inden for human- og samfundsvidenskaberne de senere år. For det andet skal de omtalte bestræbelser anskues som led i et mere omfattende forsøg på at gøre op med essentialistiske og universaliserende teoridannelser omkring mennesket og det menneskelige, ifølge hvilke fænomener som selvet, identiteten, individet og den menneskelige væren er karakteriseret ved stabilitet, kohærens, enhedslighed og almenhed. Som alternativ til sådanne teoridannelser udvikles der disse år nemlig mange nye forestillinger om mennesket og dets væremåde som karakteriseret ved differentialitet, kontekstualitet og relationalitet - en nyorientering, der ikke mindst også har vist sig nødvendig for forståelsen af det menneskelige i en senmoderne virkelighed, hvor mennesket virker i en verden mærket af bl.a. globalisering, kompleksitet, uforudsigelighed, irreversibilitet og øget forandringshastighed (Sørensen (2005)).

En stor del af disse tendenser til at skabe nye former for forståelse af mennesket og dets måde at være til på er stærkt forbundet med et forøget human- og samfundsvidenskabeligt fokus på spørgsmålet om menneskelige relationer og deres betydning for vores erkendelse, kommunikation, udvikling, livskvalitet, kultur og socialitet mv. (Perlman (2006)). Dette fokus har også vist sig inden for det fagpsykologiske felt i tilknytning til en stigende opmærksomhed mod den betydning, som mellemmenneskelige relationer og interaktioner har for den menneskelige væren og menneskets psykiske liv - for hvorledes det enkelte menneske eksisterer og udvikler sig i en nær og gensidig 
sammenhæng med andre mennesker. Omdrejningspunktet for denne artikel er i den forbindelse at redegøre for, hvordan der aktuelt foregår en stigende problematisering af mellemmenneskelige relationers indflydelse på udformningen af vores selv inden for psykoanalysen samt at diskutere, hvilke perspektiver en sådan relationstcenkning har. Denne fagpsykologiske retning er ikke ene om at interessere sig for det, vi her skal kalde det relationelle selv, men ved at gribe fat om psykoanalysen er det muligt at demonstrere en idéhistorisk udvikling hen imod en relationel opfattelse af selvet. Samtidig er det dog også artiklens hypotese, at det relationelle aspekt faktisk er til stede psykoanalysen helt fra deres begyndelse, men at spørgsmålet om relationer efterhånden har fået en meget større betydning. Derfor retter den følgende artikel sig mod at redegøre for nogle centrale karakteristika ved psykoanalysen, hvis udvikling i forståelsen af psykologien som systematisk praksis og akademisk videnskab følgende skal beskrives som den forløber i 6 faser, med særligt henblik på at undersøge, hvorfor og hvordan betydningen af menneskelige relationer i stigende grad inddrages.

\section{Metateoretisk perspektiv}

Denne artikel tager sigte på at sammenligne forskellige teorier om menneskets selv inden for en bestemt fagpsykologisk retning ud fra et bestemt tematisk fokus på betydningen af måden, hvorpå vi er til, oplever og handler i samspil med andre. Med andre ord omfavner artiklen både et teoriniveau og et praksisniveau, og for at kunne skabe refleksion og bevidstgørelse i forhold til teoriernes forskellige udgangspunkter og deres forhold til praksis, er det også nødvendigt med at metateoretisk niveau.

1. Teori og praksis: I denne artikel behandles teori og praksis ud fra en afvisning af de radikale socialkonstruktivisters og -konstruktionisters tilbøjelighed til at gøre menneskets væremåde og erfaringsdannelser til helt igennem sproglige konstruktioner og produkter. Samtidig bygges der dog også på en forståelse af, at vores erfaringer og teorier udfolder sig inden for praktiske livssammenhænge og således er afhængige tid, sted og situation. Dette indebærer derfor også en afvisning af den positivistiske forestilling om, at nyere teorier eller videreudviklinger af gamle nærmest per se har større gyldighed og sandhedsværdi end deres respektive ophav, og at teoridannelse sker uafhængigt af forandringer i menneskets materielle, mentale, sociale og kulturelle vilkår. Som antydet indebærer dette ikke en afvisning af, at der gives en objektiv virkelighed, men det påstås dels at menneskets materielle vilkår, mentale forestillinger, sociale dynamikker og kulturelle forandringer påvirker dets oplevelse af denne virkelighed på væsentlige områder (jf. Jørgensen (2002), 18). Og dels påstås det, at viden og teorier udvikles omkring menneskets problematiseringer af praktiske forhold i dets faktiske virkelighed, der på en påtrængende måde fremstår som diskuterbare eller uforklarlige, for på den måde at kunne begrebsliggøre, give mening til og lette forklaringen og håndterbarheden af disse forhold inden for en eller anden livssammenhæng (jf. Foucault (1992a), 11). Teorier og begreber 
skal derfor forstås som meningsgivende eller nyttegørende struktureringsredskaber for erfaringer af forhold i en kompleks praktisk virkelighed, der omvendt påvirkes af den måde, vi oplever, intervenerer i og skaber teorier om praksis på.

2. I det almenpsykologiske felt: Denne artikel er et almenpsykologisk projekt med en antropologisk synsvinkel og handler altså om karakteren af den menneskelige psyke som sådan med fokus på mellemmenneskelige relationers betydning for selvet. Som allerede beskrevet vil omdrejningspunktet i den forbindelse være den måde, hvorpå menneskets relationer gennem tiden er blevet problematiseret inden for en bestemt fagpsykologisk tradition. I henhold til det skitserede metaperspektiv vil de til enhver tid fremherskende psykologiske teorier og metoder på forskellig vis afspejle nogle væsentlige dimensioner i deres samtidskultur, og det vil også gælde teorierne inden for psykoanalysen. Samtidig er det også gjort gældende, at den menneskelige psykologi udfolder sig inden for rammerne af en bestemt historisk, social og kulturel kontekst, der både vil påvirke karakteren af psyken og de problemstillinger, som teorierne etableres omkring - herunder forhold ved selvet.

3. Selvet: Der har eksisteret mange forskellige konceptioner og begrebsliggørelser af mennesket med vidt forskelligt betydningsindhold i de vestlige idéers historie. Begrebet om selvet er i den forbindelse heller ikke et begreb, der kan gives én bestemt definition, og det bruges ofte synonymt med andre begreber som subjekt, personlighed, identitet og jeg. Meget bredt formuleret kan man dog lade begrebet selv henvise til en refleksiv egenskab eller den gruppe af forestillinger, der repræsenterer individet, som henviser til, at man oplever sig som en nogen og forholder sig til sig selv. I overensstemmelse med at begrebet selv både bruges i flæng med andre begreber om det menneskelige individ og som en mere specifik betegnelse for det subjektive, vil denne artikel anvende selvbegrebet på begge måder i overensstemmelse med idéen om, at forestillinger om mennesket afspejler historisk og kulturelt forankrede problematiseringer af mennesket. Psykoanalysen etableres og forandrer sig under og i overgangen mellem modernitet og senmodernitet som sociokulturelle epoker, hvilket altså må tænkes at afspejle sig i teoridannelsen og de aspekter ved menneskets væren, der problematiseres. Overordnet set karakteriserer moderniteten adfærds- og erfaringsformerne i det postfeudale industrialiserede Europa. og disse er kendetegnet derved, at mennesket i sin forståelse af og omgang med sig selv og virkeligheden installerer sig selv som sit eget og virkelighedens referencepunkt $\mathrm{i}$ stedet for at forstå sin væren som bestemt af en kosmisk eller guddommelig verdensorden. Nu forestiller mennesket sig både at kunne gøre sig selv, sin fysiske omverden og sine sociale sammenhænge gennemsigtige for sin erkendelse og mulige at beherske ved hjælp af teknik. Som Foucault gør opmærksom på, markeres denne antropologiske vending blandt andet med Kants fremstilling af mennesket som et autonomt og selvtransperent erkendende subjekt, der ved også at være genstand for erkendelsen kan gøre sig til selvstændigt objekt for viden (Foucault (1999)). Samtidig udtrykker Kant i den forbindelse i høj grad det moderne skisma imellem en liberalistisk-humanistisk 
forståelse af selvet som et subjekt udstyret med en fri vilje styret af det bevidste jeg og en mekanistisk forståelse af mennesket, der som objekt er et fysisk væsen styret af naturens lovmæssigheder. Samtidig gør Køppe og Olsen opmærksom på, at disse to menneskeopfattelser flankeres af en romatisk-humanistisk forståelse af subjektet som udstyret med en inderliggjort følsomhed og en autentisk væren (Køpe (1997)). Disse tre menneskeopfattelser afspejler på hver deres vis forhold i den tidlige modernitet: (1) Troen på oplysningsfornuften, videnskabens og teknologiens velsignelser, dannelsen af det borgerlige samfund med rettigheder for alle mennesker; (2) Fremvæksten af naturvidenskabeligt funderede videnskaber om mennesket og etableringen af mennesket som ressource i det kapitalistiske produktionsapparat; (3) Samt opnormeringen af intimsfæren med etablering af privatlivet i kernefamilien og den personliggjorte tilværelse i borgerskabet. I det 20. århundrede eroderes idéen om det frie autonome subjekt imidlertid på flere fronter, og man begynder i stedet at konceptualisere mennesket som indlejret i dets væren-i-verden (Heidegger) eller en sprogligt medieret virkelighed funderet i en praktisk livssammenhæng (Wittgenstein) eller andre sproglige, kulturelle og strukturelle sammenhænge. Samtidig begynder oplæsningen af de traditionelle fællesskaber, opløsningen af kernefamilen, den stigende sociale mobilitet og de hastigt forandrende krav til produktivitet og udvikling i den nye kapitalisme at ændre menneskets grundvilkår på en måde, som gør det mere sat af end sættende for sine omgivelser og man begynder at forstå selvet som kontekstuelt, relationelt eller differentieret (Sørensen (2005)).

\section{Psykoanalytisk perspektiv}

Psykoanalysen udgør den fagpsykologiske retning, der skal behandles som centralt teoretisk og praktisk perspektiv på relationers betydning for det menneskelige selv. Som indledning til dette afsnit er det hensigtsmæssigt at foretage en kort markering af, hvad der i denne artikel overhovedet menes med betegnelsen psykoanalyse, og hvordan der vil blive gjort rede for den som fagpsykologisk retning: Det er ikke ualmindeligt at skelne mellem psykoanalyse og psykodynamisk teori og praksis, hvor sidstnævnte udspringer af og er udviklet med teoretisk og metodisk inspiration fra Freuds oprindelige lære men uden at overholde de særlige regler og konceptualiseringer, der gælder for den klassiske psykoanalyse - som betegnelse for en form for sammenhængende (1) terapeutisk metode, (2) metode til analyse psykiske processer og (3) almenpsykologisk teori om personligheden - med dens fokus på idéerne om ubevidste processer, konflikter og forsvar, Ødipus-komplekset og seksualitetens betydning for udvikling af personlighed og neurose. I denne artikel vil begrebet psykoanalyse, i overensstemmelse med en anden opfattelsesmåde, imidlertid blive brugt som fællesbetegnelse for både den klassiske psykoanalyse og for de senere retninger, der er udviklet i

direkte forlængelse heraf, og som i fællesskab danner konturerne af én sammenhængende tankeformation omfattende en flerhed af skoler, tekniske terminologier og kliniske praksisformer (jf. 
f.eks. Mitchell (1995); Westen (1999)). Samtidig vil der i redegørelsen for psykoanalysen blive lagt særligt vægt på den måde, hvorpå menneskelige relationer er blevet behandlet inden for denne tankeformation fra Freud og frem til i dag. Dette vil endvidere især ske med henblik på at kunne gøre rede for de aktuelle udviklingstendenser i psykoanalysen, som flere har benævnt en relationel vending, og som bl.a. har udmøntet sig i etableringen af en egentlig relationel psykoanalyse (Mitchell (2003), xiii). Hermed peges der dels på, hvordan det traditionelle psykoanalytiske paradigme i de seneste årtier er blevet udfordret indefra gennem udviklingen af en forståelse af, at psyken har en relationel karakter, og på hvordan denne forståelse har fået vidtfavnende indflydelse på tværs af forskellige skoler og kliniske modaliteter. Dels peges der på, hvordan denne tendens kan siges at afspejle sig i fremkomsten af en såkaldt sjette fase inden for de psykoanalytiske teoriers historie, der gør relationer til sit centrale fokus. I det følgende skal der gøres rede for begge disse dimensioner med baggrund i en afdækning af psykoanalysens historiske udvikling og etablering i et bestemt videnskabshistorisk landskab.

\section{Etableringen af den videnskabelige psykologi}

Med henblik på at beskrive etableringen af psykoanalysen, kan det være væsentligt at se på nogle træk ved det fagpsykologiske landskab i slutningen af det 19.århundrede. For en idéhistorisk betragtning er det først og fremmest muligt at anskue Freuds dannelse af psykoanalysen i Østrig som en del af samtidens bestræbelser på at gøre det tidligere filosofiske studie af psykologi til et empirisk videnskabeligt studium. Psykoanalysen fremkommer nemlig nogenlunde parallelt med, at psykologien i Tyskland etableres som en eksperimentel videnskab på et selvstændigt grundlag omendskønt med et ganske andet fokus end psykoanalysen:

Idéhistorisk set kan psykologien siges at etablere sig i det 19. århundrede som en selvstændig videnskab om det mentale liv gennem en udparcellering og videnskabeliggørelse af nogle bestemte problemstillinger vedrørende psûché eller sjælen, der hidtil var blevet behandlet på et filosofisk grundlag (Saugstad (1998) kap.1-3). Denne videnskabeliggørelse involverer et forsøg på at opstille nogle nye krav til empiri samt opfylde nogle mere skærpede krav til teori og metode. Ifølge Christensen dannes hermed konturerne af en specialvidenskab, som, med afsæt i Habermas’ refleksioner over forholdet mellem videnskabelig erkendelse og interesse, forefindes i en overordnet placering $\mathrm{i}$ et spændingsfelt mellem tre videnskabelige hovedområder: Humanvidenskab, naturvidenskab og samfundsvidenskab (Christensen (2005), 81; Bertelsen (2003), 23). Betragter man psykologiens videnskabshistorie, er der imidlertid stor forskel på hvilket videnskabeligt hovedområde, som de forskellige retninger inden for psykologien lægger vægt på at forstå dem selv i tilknytning til samt, hvilke genstandsmæssige emneområder inden for menneskets mentale liv, der er interessefokus.

Psykologiens etablering som videnskab henregnes ofte til Wundt (og Fechners psykofysik), der udvikler en systematisk empirisk udforskning af bevidstheden, som psykologiens ontologisk 
afgrænsede genstandsfelt med brug af eksperimentelle metoder efter naturvidenskabeligt forbillede. Dette hænger dels sammen med, at man i det 19. århundredes eksperimentalpsykologi betragter psykologiens genstand som nært tilknyttet fysiologiens genstand, og i Wundts udlægning af det psyko-fysiske problem er psykiske bevidsthedsprocesser og fysiologiske nervesystemsprocesser korresponderende og to parallelle aspekter af samme fænomen. Ud fra en atomistisk associationistisk tilgang til bevidstheden - som bygget op af associerede elementer - iagttager eksperimentalpsykologien forholdet mellem ydre stimulus og indre respons gennem undersøgelse af det, som antages at være bevidsthedens elementære funktioner (primært sansning og perception) ${ }^{1}$. Disse betragtes som målbare og kontrollerbare - og dermed kvantificerbare - størrelser, og gennem metodisk reduktionisme forsøges det at borteliminere den subjektive oplevelsesdimension (qualia)(Christensen (2005), 52-5; Saugstad (1998), 97-115). Der er med andre ord tale om en videnskab med et mekanistisk menneskesyn, hvor spørgsmålet om selvet som sådan ikke melder sig som relevant. Wundts eksperimentelle psykologi kan i den forbindelse betragtes som et forsøg på at etablere psykologien som en objektiv eksperimental gren af naturvidenskaben i positivistisk forstand, der som nomografisk videnskab skal finde almene lovmæssigheder for bevidstheden ${ }^{2}$. Videnskaben knytter her an til en realistisk og empiristisk erkendelsesteori og baseres på introspektive studier i laboratoriet med henblik på at sikre kontrollerede settings med kalkulerbare fejlkilder.

\section{Første fase: Forførelsesteorien}

Psykoanalysen repræsenterer ikke et lukket logisk system men et stadigt uafsluttet produkt af forskning og klinisk erfaring, og Freuds teoretiske udvikling kan da også beskrives som en gradvis erkendelsesproces i flere stadier, hvoraf det første af disse stadier kan siges at repræsentere psykoanalysens første bølge. Denne position havde også den nomotetiske naturvidenskab som ideal, men modsat Wundts videnskabelige psykologi var den ikke en eksperimentel psykologi, og dens praksis var heller ikke lokaliseret til laboratoriet. Freuds ambition om at etablere en videnskabelig psykologi udsprang nemlig ikke primært gennem inspiration fra datidens eksperimentelle naturvidenskabelige laboratorieforskning men under indflydelse af terapeutiske erfaringer i tilknytning til det terapeutiske fokus på patologier inden for psykiatrien og neurologien, især de ikkepsykotiske neurosetilstande som hysteri, hypokondri og neurasteni, der især forekom blandt

\footnotetext{
${ }^{1}$ Hermed ligner Wundt sine filosofiske forgængere, de britiske filosofiske empirister, der forfægtede associationismen.

${ }^{2}$ Ifølge den positivistiske tradition fra Comte, Mill og Mach er alle former for videnskabelig viden defineret ved at må være baseret på analyse af direkte sanseerfaringsmæssig erkendelse gennem brug af en ensartet videnskabelig metode (som regel induktion). På baggrund af observation af objektive empiriske kendsgerninger kan man nemlig nå frem til en sand videnskabelig forklaring af lovmæssighederne i verden, og den logiske positivisme hos bl.a. Carnap og Ayer siger tilsvarende, at vores udsagn kun kan være kognitivt meningsfulde ved at give et realistisk og verificerbart billede af den iagttagelige verden, mens udsagn om uverificerbare vurderinger, værdier og andre subjektive fænomener er kognitivt meningsløse og derfor ikke kan gøres til genstand for videnskab (jf. Ayer (1990)).
} 
hjemmegående kvinder fra borgerskabet med manglende beskæftigelsesmuligheder (Køppe (1997), 123). På daværende tidspunkt var videnskaben mest interesseret i de svære psykiske lidelser, der enten blev opfattet gennem en socialdarwinistisk optik som degenerative sygdomme eller - og især - via den nye neurofysiologi som organisk funderede nervelidelser i hjernen. Trods den stigende udbredelse blandt borgerskabets kvinder var de lettere neurosetilstande derfor videnskabeligt uudforskede og meldte sig derfor som uforklarlige og uhåndterlige for lægevidenskaben. På baggrund af empiriskterapeutiske erfaringer problematiserede Freud disse tilstande og lancerede en ny forståelse af hysteriens ætiologi og terapi ${ }^{3}$, hvor fokus blev flyttet fra neurofysiologiens optagethed af hjernen til bevidstheden: Hysteri var ikke en hjerne- men en bevidsthedslidelse, hvis årsag var undertrykkelse af bestemte patogene oplevelser med et traumatiserende indhold af seksuel karakter, som var inkompatibelt og i konflikt med personens øvrige bevidsthedsindhold. Dermed blev oplevelserne gennem fortrcengning dissocieret fra bevidstheden i en spaltning af psyken og omordnet til ubevidste idéer, der ved hjælp af forsvaret blev holdt aktivt ude af "tænkeforegangen” (Freud (1980), 105; (2004), 226). Med distinktionen mellem det bevidste og det ubevidste område overskred Freud den simple bevidsthedspsykologi, og dette topiske aspekt i spaltningsteorien var associeret med et økonomisk aspekt, ifølge hvilken fortrængningen og forsvaret betød, at affekterne forbundet med de traumatiske oplevelser blev udkanaliseret i medieret form som patologiske symptomer - modsat umiddelbart som seksualitet og aggression. I perioden mellem 1895 og 1897 forstod Freud disse traumatiske reminiscenser ud fra den såkaldte forførelsesteori, ifølge hvilken årsagen til hysteriens symptomer var traumatiske oplevelser i barndommen i form af seksuelle overgreb fra voksne - oftest incestuøs forførelse. Som Foucault gør opmærksom på, afspejlede og artikulerede Freud hermed samtidens voldsomme interesse for seksualitetens betydning for subjektets konstitution i sin teori (Foucault (1994)). Hvor Wundts undersøgelse af sansningernes association til bevidstheden i kontrollerede laboratorieeksperimenter gjorde menneskets livsverden til en biasfaktor, angav Freuds teori med andre ord en menneskelig relation i en social kontekst som årsag til psykoneurosen, derved at et andet menneske udefra invaderer bevidstheden på en destruktiv måde ved at introducere seksualiteten i det præmature og af naturen uskyldige barns erfaringsverden: En i barndommen rationelt uforståelig erfaring, der er forbundet med stærke affekter, som på dette tidspunkt bliver ufuldstændigt eller forkert afreageret. Barndomserfaringen finder sted i en initial fase, og efter pubertetens indtræden "gentages” den i en ny fase af en ny hændelse og fortrænges i den ombæring med forsinkelse af forsvaret som affektladet attentaterindring og udløser et traume (Freud (1980), 113). Den genaktualiserede oplevelse kan med andre ord ikke bemestres, og som et resultat af den hermed sammenhængende fortrængning bliver de voldsomme affekter forbundet med det ydre sanseindtryk

\footnotetext{
${ }^{3}$ Freud inddelte de mildere nervøse lidelser i aktualneouroser (neurasteni, angstneurose) og psykoneuroser (hysteri, tvangsneuroser), hvoraf kun de sidsnævnte var relevante for psykoanalysen (Olsen (1997), 123)
} 
konverteret til et kropsligt symptom, der ikke kan påvises at have et neurologisk, dvs. objektivt grundlag. Freud opdagede i forbindelse hermed, at det ved hjælp af den frie associations metode, som en psykoanalytisk taleterapi, var muligt at give det fortrængte materiale en mulighed for at komme til udtryk ved at blive genoplevet og afreageret og dermed afstedkomme en frigørelse fra de uhensigtsmæssige psykoneurotiske reaktionsmåder.

I tilknytning til disse analytiske erfaringer med hysterien opstillede Freud i Udkast til en videnskabelig psykologi en naturvidenskabeligt inspireret almenpsykologisk refleksmodel over personligheden som et dynamisk system af kvantitativt opfattet psykisk energi. I denne model overførtes Helmholtz' princip om energiens konstans i lukkede systemer fra thermo- til psykodynamikkens område, ud fra antagelsen om at de psykiske processer forsynes med drivkraft fra energi, og at denne energi må følge de samme love som andre energiformer i naturen. Individet besidder derfor en konstant mængde psykisk energi gennem sit liv, der kan dirigeres i forskellige retninger, og de patologiske tilstande måtte forstås som resultat af en opstemning af energi på grund af traumet. Kunne denne energitilvækst ikke afreageres, kom systemet under tryk, og energien blev i henhold til det økonomiske aspekt udladet på en uhensigtsmæssig måde, kropsligt eller psykisk. Hvor de kliniske beskrivelser havde en tendens til udelukkende at beskrive psykoneuroserne som mentale lidelser i psykologiske termer (jf. Freud (2004), 189) påstår Freud her, at de psykologiske processer forløber parallelt med fysiologiske processer. I forhold til det psykofysiske problem kan denne personlighedsmodel siges at være forbundet med en monistisk identitetsteori, hvor psyken har to ækvivalente sider, der kan beskrives på kvalitativt forskellige niveauer: En neurofysiologisk og en mental side

"Bevidsthed er her den subjektive side af en del af de fysiske foregange i neuronsystemet, nemlig af sansningsforgangene (Freud (1980), 43).

I tillæg til at etablere psykoanalysen som en analytisk metode og en terapeutisk teknik forsøgte Freud således på baggrund af analytiske erfaringer og nogle naturvidenskabelige teorier at opstille almene modeller og hypoteser om personligheden og det psykiske apparat, der skulle kunne forklare menneskets bevidsthed og adfærd men uden en ambition om at suspendere det subjektive aspekt som i den eksperimentelle laboratoriepsykologi. I den forbindelse er det væsentligt, at Freuds psykologiske videnskabsteori knytter an til en kantiansk inspireret anti-realistisk erkendelsesteori, hvor virkeligheden i sig selv ligger uden for erkendelsens rækkevidde - derfor skal hans videnskabelige hypoteser omkring det psykiske apparat også opfattes som skematiske konstruktioner til forklaring af nogle ellers uforklarlige fænomener og relationer og ikke forveksles med selve virkeligheden (Madsen (1986), 250-3). Samtidig må det tilføjes, at Freud i sine refleksioner over personligheden og dens udvikling også lægger vægt på livshistorien og betydningen af kulturelle faktorer, hvorfor psykoanalysen må inddrage kvalitative idiografiske metoder i form af hermeneutisk fortolkningsvirksomhed i kombination med at trække på idealet om at være en nomotetisk 
naturvidenskab. Freud adskiller sig således fra den positivistiske tradition ved inddragelsen af humanvidenskabelige metoder og adoption af teorier og modeller fra f.eks. fysikken på andre genstandsområder, samtidig med at han inddraget filosofisk refleksion og syntesedannelse fremmed for den rent erfaringsbaserede teoridannelse.

\section{Anden fase: Driftsteorien}

Efter 1897 opdager Freud, at mange af hans neurotiske patienter faktisk ikke er incestofre, og han forlader derfor forførelsesteorien som hypotesen om, at årsagen til enhver psykoneurose er en seksuel forførelse. I stedet ændrer han sin teori fra at omfatte reelt eksisterende forførelser til at omhandle undertrykte seksuelle ønskefantasier i barndommen. Med denne teori om den infantile seksualitet får neuroseteorien et nyt grundlag, der overordnet set er forbundet med en ændret opfattelse af det relationelle aspekt omfattende en forskydning fra et inter-psykisk fokus på mennesker i den ydre virkelighed og deres indvirkning på psykiske processer til et intra-psykisk fokus på den indre verden: Årsagen til neurosens udvikling var dybest set ikke længere den voksnes udefra kommende seksuelle korrumpering af det uskyldige barn, men et endogent pres fra barnets egne seksuelle ønsker, og i denne teoriudvikling bliver konkrete relationer til andre sekundære (Mitchell (1988), 2-3; (2003), x). Ifølge Freud var en sådan konfliktuel seksualitet imidlertid ikke kun et kendetegn for neurotikerens barndom men for alle menneskers barndom, og teorien om den infantile seksualitet blev endvidere baseret på den såkaldte driftsteori:

Kilden til den psykiske energi må nu søges på det kropslige plan i driftspirringer fra fysiologiske processer i organismens indre - modsat ydre pirringer fra sansestimuli - og målet for disse drifter er at søge spændingsudløsning (Freud (1974), 124). I første omgang skelner Freud mellem selvopretholdelses- eller jegdrifter (forbundet med ernæringsfunktionens processer) og seksualdrifter som energikanaler, og drifterne kommer i den forbindelse til udtryk på det psykiske plan enten gennem energiformen jeginteresse som følelsen sult eller gennem energiformen libido som følelsen kærlighed (ibid 93). På dette plan er drifterne repræsenteret som dispositioner for noget bestemt på den måde, at deres mål som motiverende kræfter er at tilfredsstille menneskets medfødte fysiologiske behov ved at være rettet mod objekter for opnåelse af behovstilfredsstillelsen (ibid. 128) - relationer til omverdenen konstitueres altså sekundært som midler for menneskets behov. På aktionsplanet med de motoriske reaktioner viser drifterne sig så som tilbøjeligheder til at handle således, at der faktisk opnås behovstilfredsstillelse og spændingsophør. Fra den såkaldte energi-økonomiske synsvinkel kan drifterne hermed siges at repræsentere fysiologiske krav til det psykiske og handlingsmæssige liv og ved at anskue drifterne som de mest oprindelige funktioner i subjektet, involverer driftsteorien for alvor en forskydning af psykologiens genstandsfelt bort fra associationismens interesse for sansningernes relation til bevidstheden. 
Fra den dynamiske synsvinkel knyttes drifterne nært til to psykiske procestyper relateret til to funktionsprincipper, hvilket for Freud er forbundet med en idé om, at det psykiske apparat styres af to modsatte kræfter. I barnets første leveår styres det først og fremmest af primcrprocesser, der uden hensyn til realiteter forløber umiddelbart mod uhæmmet tilfredsstillelse af barnlige behov og ønsker efter lystprincippet som en tendens til at opnå lyst og undgå ulyst. Disse primærprocesser står i modsætning til det voksne menneskes senere udviklede sekundcerprocesser, der fungerer regulerende for tilfredsstillelsen af ønsker og behov efter realitetsprincippet som tendensen til at orientere sig efter de fysiske, moralske og kulturelle reale betingelser. Personligheden som helhed rummer både primærprocesser og sekundærprocesser, og efter den tidligste barndom er det sekundære system sæde for jegdrifterne mens de konfliktuerende seksualdrifter mest findes i det primære system. Det sekundære system er mere præcist identisk med det endeligt udviklede jeg, som er Freuds begreb for selvet, og dets funktion er at regulere primærsystemets processer. I den tidligste barndom findes alle drifterne imidlertid i det primære system, og barnet udvikler et lystjeg, der, uden at drage grænser mellem individ og omverden, kun har sig selv og ikke noget fremmed objekt som genstand for tilfredsstillelse. I individets normale udvikling overskrides denne primære narcissistiske fase, og jegdrifterne retter sig mod ydre objekter, danner sekundærsystemet og går mod at binde seksualdrifterne til jegdrifternes ydre objekter - efter visse partialobjekter i første omgang moren som objektlibido i introjicering af objekterne i tilknytningen. Lykkes tilknytningen til disse objekter ikke bliver seksualdrifterne bundet til individets eget jeg som jeglibido i en sekundær og patologisk narcissisme, der kan føre til psykoser (ibid 90).

Fra den topografiske synsvinkel er de omtalte primærprocesser identiske med processerne i det såkaldte ubevidste erindringssystem, som fungerer efter lystprincippet ved at rumme hele personlighedens energi- og motivationsgrundlag. Teorien om det ubevidste markerer en decentrering af det bevidste subjekt og en ny forståelse af det menneskelige subjekt som rummende forskellige kvaliteter og kræfter, hvorfor individet ikke længere kan forstås i henhold til den liberalistiske subjektopfattelse som "herre i sit eget hus”. Ud over at være utilgængeligt for bevidstheden er forestillingsindholdet i det ubevidste umiddelbart, ufornuftigt og nonverbalt og repræsenterer lystjeg'et som et tidligt stadie i individets udvikling. For at de psykiske processer i det ubevidste kan blive bevidste i systemet af bevidst forestillingsindhold må de først overføre deres impulser til det førbevidste system med verbale forestillinger og her få sekundærproces-karakter. Som det sekundære system indeholder det førbevidste og det bevidste til sammen det endelige fornuftsbetonede og realitetsorienterede jeg, og mens dette jeg har et normalt udviklet forsvar, som består i at foregribe og tolerere ulyst på en hensigtsmæssig måde, skyldes neurosen enten, at nogle ubevidste forestillingsimpulser hindres adgang til at oversættes og få bevidst udtryk af et patologisk forsvar, eller at andre forestillinger fortrænges fra det bevidste eller førbevidste til det ubevidste system og derfor heller ikke kan få realitetsorienteret og fornuftsbetonet udtryk i bevidstheden. Disse 
forestillinger er nemlig uforenelige med jeg'et og stedet for at få et normalt udtryk i det bevidste system, presser forestillingerne sig på og kommer til udtryk som neurosens forstyrrede psykopatologiske bevidsthedsformer. Som allerede nævnt er der hermed tale om visse ønskeforestillinger forbundet med seksualdrifter, og i barndommen bestemmes seksualiteten ud fra en række partialdrifter, der er knyttet til forskellige erogene kropszoner og udvikles i en række successive psykoseksuelle stadier (den orale, anale, falliske og genitale fase). I overensstemmelse med romantikkens dannelsesideal skyldes neuroser i voksenlivet en forstyrret udfoldelse af nogle elementer i den infantile seksualitet. Disse elementer konvergerer udviklingsmæssigt ved at blive samlet under den genitale seksualitet omkring 5 års alderen i organiseringen af det såkaldte Ødipuskompleks, hvor barnet ønsker at have sex med den modsatkønnede forælder og derfor destruere den samkønnede forælder (Quinodoz (2004, 62). De objektbindinger som jeg'et her etablerer er forbundet med erfaringen af relationer til nogle faktiske primærpersoner i den småborgerlige kernefamilie, og igen ses det at relationsaspektet faktisk er til stede i den klassiske psykoanalyse. Ud fra et almenpsykologisk perspektiv skal disse faktiske relationer imidlertid i høj grad forstås intrapsykisk - hvilket involverer en forskydning af forståelsen af det incestuøse element bort fra en interpsykisk tematisering - og dermed også som sekundære i forhold til udviklingen af individets psykiske apparat. Mens Freud forstod sin teori som universel, er det her ikke uvæsentligt at bide mærke i, at den afspejler refleksion over nogle problemstillinger i forbindelse med den opnormering af intimsfæren, der gjorde sig gældende med etableringen af den borgerlige kernefamilie som væsentlig, men ikke altdominerende, samfundsmæssig mikroenhed i samtiden og derfor ikke er så almengyldig, som den gerne vil være (jf. Køppe (1997)).

\section{Tredje fase: Jegpsykologien}

Det relationelle aspekt bliver mere eksplicit i egopsykologien, der kan siges at blive indledt med Freuds etablering af en strukturel model for funktionsområderne i personligheden i kølvandet på en revidering af driftsteorien.

Den tidlige driftsteori var som nævnt baseret på en antagelse om, at neuroser skyldtes konflikter mellem fornufts- og realitetsorienterede kræfter i det førbevidste system og følelses- og lystorienterede kræfter i det ubevidste system. I sit kliniske arbejde bemærker Freud omkring 1920 imidlertid i stigende grad den problemstilling, at nogle patienter udviser aggressiv eller gentagen selvdestruktiv og ulystfuld adfærd og at deres lidelse derfor tilsyneladende ikke er funderet i en konflikt mellem realitets- og lystprincippet (Freud (1976), 33). Som løsning omfordeler Freud driftsøkonomien til en grundlæggende driftsdualisme mellem dødsdriften, som søger tilbage mod en uorganisk livstilstand, og livsdriften, der under ét omfatter jeg- og seksualdrifter og er forbundet med energiformen libido (Freud (1998), 18). Menneskets psykiske lidelser fremkaldes gennem undertrykkelse af drifterne i det enkelte individ, men Freud gør, i lighed med statsteoretikeren 
Hobbes, også opmærksom på, at en vis moderat social kontrol af i et hvert tilfælde primitive seksuelle impulser og især dødsdrifter er nødvendig for samfundets opretholdelse og kulturens udvikling (Freud (1975)). Med andre ord spiller sociale relationer en væsentlig rolle for det kulturelle menneskes overlevelse og dannelse som selv, uden at det enkelte menneske som sådan er hverken bevidst om eller tilfreds med denne undertrykkelse, og denne tilsyneladende ubevidste fornuftsmæssige selvkontrol ser Freud også i den kliniske praksis.

Freud reflekterer fra 1920'erne i stigende grad over den problemstilling, at patienterne ikke synes at være bevidste om alle de fornuftsbetonede og realitetsorienterede sider af dem selv, der indgår som forsvars- og fortræningselementer i neurosens underliggende konflikt og f.eks. viser sig som skyldfølelse, forbudspålæggelse og selvstraffende adfærd (Freud (1976), 173). Konflikten foregår med andre ord ikke så meget mellem det bevidste og det ubevidste men inden i det ubevidste, hvorfor der måtte indgå flere forskellige funktionstyper end jeg’et i det psykiske apparat (Freud (1998), kap 1). Parallelt med de tre topiske dimensioner ubevidst-førbevidst-bevidst bliver der således tale om de tre strukturdimensioner det-jeg-overjeg som delkomponenter af selvet: Det'et indeholder alt biologisk nedarvet og de fysiologisk bestemte drifter som primærprocesserne samt senere fortrængt materiale, og i begyndelsen af barnets udvikling er det dominerende og uadskilleligt fra jeg'et, der som spæd identitetsfølelse repræsenterer individets forestilling om sig selv (Køppe (1997), 379). Det psykiske apparat består mao. af et udifferentieret jeg-det, men grundet påvirkninger fra den ydre verden får jeg'et imidlertid gradvis en mere selvstændig funktion ved at agere formidler mellem denne verden og det'et. I lighed med den tidligere udviklingsbeskrivelse bliver jeg'et især udkrystalliseret fra det'et ved at indgå i tilknytninger til og identificeringer med andre mennesker i omverdenen som objekter, hvormed aspekter af objekternes værdier, egenskaber og personlighedstræk internaliseres og aflejres i jeg'ets egen karakter (Freud (1976), 174). Her får mellemmenneskelige relationer altså igen en forøget status for selvets udvikling, og dette forøges i forlængelse af barnets opdagelse af umuligheden i ødipuskonflikten. Nu fortrænges ødipuskomplekset til det'et, og barnet vender tilbage til mere stabile relationer til forældrene for at udvikle identificeringen med dem og senere med andre vigtige personer. I den proces aflejres forestillinger om forældrenes aktive egenskaber som over-jeget i form af idealer og moralbud, som jeg'et hele tiden må adlyde, samtidig med at det må indrette sig efter de kærlighedsobjekter, det møder i sit liv. Kulturens sociale kontrol aflejres også i overjeg'et som delvist ubevidste mekanismer til regulering af det jeg, der ved uddifferentieringen fra det'et udvikler sine egne funktioner som har selvopretholdelse til opgave: udadtil ved at håndtere stimuli og indadtil ved at kontrollere driftskravene fra det'et og opfylde kravene fra overjeget og i forhold til sig selv opretholde sin selvstændighed samt mekanismen angst til at skabe ressourcemobilisering ved farer (Freud (1994), 45). Ud fra et almenpsykologisk perspektiv er det altså interessant, at den nye strukturelle model for selvet betyder, at mellemmenneskelige relationer får en forøget betydning i forståelsen af selvets udvikling. Mens den tidligere driftsteori lagde vægt på barnets ønsker til objekter begynder 
Freud altså at undersøge måden, hvorpå disse libidoobjekter selv bliver internaliseret i barnet. Driftslivet vedbliver med at være den grundlæggende motor i den menneskelige organisme, men udviklingen af menneskets psykologi og personlighed i stigende grad sker i et samspil mellem de konstitutionelle drifter og konkrete relationer til andre mennesker om end disse etableringen af disse grundlæggende set også må forstås ud fra driftsøkonomien.

Selv om dette er et almenpsykologisk projekt, skal det desuden bemærkes, at relationsaspektet også er fremtrædende i Freuds psykoanalyse forstået som terapiform: Som tidligere antydet beror terapien i udgangspunktet på relationen mellem en frit associerende patient og en fortolkende analytiker, hvilket Foucault gør opmærksom på indebærer en adoption og udvidelse af bekendelsesritualet i det kristne pastorale (Foucault (1994)). Mens psykotikerens jeg-organisation er opløst og derfor ikke kan reddes gennem analyse, er analytikerens opgave i denne relation at hjælpe den neurotiske patients jeg, der er knapt så svækket i dets konflikt med det'et og overjeget (Freud (1994), 47). Neuroserne har som nævnte deres oprindelse i barndommen, således at den ellers modne voksne blot ligger under for konflikter, hvori vedkommende allerede led nederlag som barn. Hensigten med analysen er at overvinde modstanden og fjerne fortrængningerne så det ubevidste gøres bevidst, og det modne jeg får en mulighed for at løse sine konflikter på ny ved hjælp af analytikeren, der i et vist omfang må "træde i forældrenes” sted og repræsentere et mere hensigtsmæssigt overjeg (ibid 48). Som led i analysen vil patienten i form af overføring også reproducere sit ambivalente forhold til forældrene til analytikeren, der grundet sin manglende evne til at tilfredsstille patientens kærlighedsbehov i den positive overføring vil fremkalde en gentagelse af patientens oprindelige oplevelse af nederlag i barndommen i den negative overføring. Analytikeren må her gøre patienten opmærksom på, hvordan overføringen er en afspejling af relationer i fortiden, og den nuværende relation mellem analytiker og patient bliver altså på flere måder et redskab til at skille fortid fra nutid og skabe helbredelse.

Freuds psykoanalyse markerede et opgør med idéen om det autonome subjekt med en fri bevidsthed uden at havne i rent mekanistisk menneskeopfattelse, og må med sin opfattelse af jeget som koordinerende instans i forhold til virkeligheden, samvittigheden og drifterne placeres mellem en psykodynamisk deterministisme og libertarianisme (Bertelsen (2005), 40). Det programmatiske fokus på jeg’et som central struktur videreføres og forstærkes i den såkaldte jegpsykologi, hvor børneanalytikeren Anna Freud bl.a. videreudviklede teorien om jeg'ets forsvarsmekanismer ud fra refleksion over erfaringer fra det praktiske arbejde med børn. Freud antog at jeg'et anvendte forsvarsmekanismer som strategier for at beskytte sig mod angst, og Anna gjorde gældende at denne beskyttelse viste sig ved, at jeg'et ubevidst forvrængte opfattelsen af virkeligheden gennem f.eks. fortrænging, benægtelse, projektion og rationalisering (Freud (1984a+b)). Disse forsvarsmekanismer udvikles fra infantile til mere komplicerede former i barndommen som tilpasningsstrategier barnet gradvist lærer sig og automatiserer i mødet med omverdenen, og hermed påpeges det igen at 
mennesket ikke er nogen ø men udvikler sig i relationer til andre. Denne betoning af barnets tilpasning til dets sociale miljø videreudvikles i andre dele af jegpsykologien, der overordnet lægger meget vægt på sammenhængen mellem drifterne og jegudviklingen (Mitchell (1995), ch 2).

\section{Fjerde fase: Interpersonel psykoanalyse, objektrelationsteori og tilknytningsteori}

Mens jegpsykologien overordnet set problematiserede de sociale relationers betydning som sekundære ud fra menneskets grundlæggende motivering fra drifter, får relationernes betydning en langt mere fremtrædende status fra 1950'erne - i det følgende beskrevet i tre typer af teorier. Baggrunden er blandt andet, at patienternes symptombilleder begyndte at ændre sig i den kliniske praksis, ved at flere patienter udviste lidelser i dag bl.a. kendt som såkaldte personlighedsforstyrrelser, der involverer markante brist i de interpersonelle relationer. Som Jørgensen gør opmærksom på, er fremvæksten af disse lidelser i høj grad en konsekvens af udviklingen i den senmoderne kultur med modsætningsfyldte krav og samt eroderingen af de traditionelle fællesskaber som kernefamilien, og dermed kan forandringen af den psykoanalytiske teori også siges at afspejle en materiel, kulturel og socialt påvirket forandring af den menneskelige psykologis konflikter (Jørgensen (2006),ch 2). Med vægt på systematisk refleksion over de nye kliniske erfaringer lægges der nu på forskellig vis an til en omvurdering af driftsteoriens status sådan, at menneskets motiver helt grundlæggende anskues som rettet mod relationer til objekter i stedet for at være rettet primært mod behovstilfredsstillelse og sekundært mod objekter.

1. Denne såkaldte relationelle vending af psykoanalysen markerer mere en fokusændring end fremkomsten af en radikal og væsensforskellig teoridannelse inden for psykoanalysen ved at udgøre en markant uddybelse af relationsaspektet i jegpsykologien. Vendingen initieres allerede i 1930'erne med Sullivans interpersonelle psykoanalyse, der tager afsæt i et erfaringsbaseret opgør med Kraepelins neuropsykiatriske fremstilling af skizofrene som levende i deres egen verden og afskåret fra relationer med andre mennesker (Mitchell(1995), 60). Hertil gør Sullivan gældende, at den skizofrene lige omvendt er ekstremt følsom over for sit interpersonelle miljø, og at psykopatologi generelt hverken skal forstås neurofysiologisk, som hos Kraepelin, eller ud fra individets indre psykiske processer, som i den klassiske psykoanalyse, men ud fra de dysfunktioner, som patienten varetager i sine interpersonelle relationer. Hos Sullivan bliver begreberne om selv - i stedet for jeg - og interaktion afgørende for forståelsen af disse forstyrrelser i samspillet med andre, idet de må begribes ud fra den måde, hvorpå selvet grundlæggende udvikles gennem tilpasningsstrategier i interaktionen med andre mennesker i det interpersonelle miljø. I jegpsykologien antog man, at mennesket er et individ stillet over for den sociokulturelle omverden, og at det ved at være dannet af konstitutionelle drifter og et jeg formet gennem interaktion med denne omverden har en grundlæggende væremåde, hvori det er udspændt imellem en lystorientering og en forsvarende regulering af denne lystorientering. Lidt parallelt hermed antager Sullivan, at mennesket helt fundamentalt set er et 
relationssøgende socialt væsen, der i sin grundlæggende væremåde er udspændt mellem et behov for tilfredsstillelse og et behov for tryghed, som hver især genererer integration med andre mennesker (Sullivan (1997), 37-45). Mens Freud så videre antog, at neuroserne var funderet i utilfredsstillede og undertrykte ønsker og fantasier, ser Sullivan imidlertid ikke menneskets indre behov for tilfredsstillelse eller tryghed som muligt problemskabende dimensioner i dem selv. Årsagen til de psykiske konflikter skal derimod søges i den måde, hvorpå angst introduceres fra andre mennesker i den interpersonelle interaktion - i første omgang moren - og overtages som erfaring af barnet. Barnets angst opstår altså gennem en såkaldt empatisk linking i interaktionen med moren eller andre omsorgsgivende personer som en konsekvens af barnets registrering af deres angst, og angsten bliver et grundmønster for enhver disintegration i forhold til en harmonisk interpersonel situation og dermed for dets behov for tilfredsstillelse og tryghed. Sulivan anskuer psyken som dynamiske størrelser, og mens tilfredsstillelse og tryghed er en konjunktiv dynamik, der integrerer barnet i interpersonelle situationer, er angsten derimod så en disjunktiv dynamik, der lige netop disintegrerer barnet fra det sociale miljø. Gennem personifikationer udvikler barnet mentale repræsentationer af de interpersonelle erfaringer, og barnet etablerer på den baggrund en grundlæggende erfaringsmæssig skelnen i sig selv mellem en prototypisk forestilling om en god mor for oplevelser præget af tryghed og behovstilfredsstillelse og om en dårlig mor for oplevelser præget af angst (ibid 111-124). Dernæst etablerer barnet en erfaring af, at nogle af dets adfærdsformer genererer angst hos moren eller andre omsorgspersoner, mens andre aktiviteter fremkalder afslappet og positiv respons, og på den baggrund etablerer barnet så en grundlæggende erfaringsmæssig skelnen mellem en prototypisk forestilling om et godt mig og et dårligt mig - samt endelig en forestilling om et ikke-mig ud fra erfaringen af at fremkalde intens dissocierende angst. Jeg har antydet, hvordan jegpsykologien i stigende grad problematiserede jegets tilpasning til sin omverden uden dog i særlig grad at specificere denne omverden, og her går Sullivan et skridt videre ved at beskrive, hvordan barnet vil tilpasse sig sit interpersonelle miljø på baggrund af disse grundlæggende erfaringsdannelser. Individet er nemlig lige præcist ikke en selvstændig enhed, idet dets selv er uadskilleligt fra dets interpersonelle miljø, og således udvikler barnet sit selvsystem i interaktionen med andre i en vedvarende bestræbelse på at forøge oplevelsen af behovstilfredsstillelse og tryghed og formindske oplevelsen af angst (ibid 164-8). Sullivan taler desuden om, at selv-systemet tillige udfører sikkerhedsoperationer som kortsigtede manøvrer for at undgå angst og styre erfaringen i retningen af det kendte og trygge interpersonelle miljø. Disse operationer betyder dog, at de angstforårsagende situationer reelt set bevares som angstfremkaldende, og ændres individets selvforståelse ikke vil det som voksen angst udløses i typer af situationer, der i opvæksten udløste angst. Lig Freud skal grunden til det voksne menneskes psykopatologiske problemer skal således søges i den måde, selvsystemet er udviklet i den tidlige barndom. Ved svære lidelser som skizofreni og personlighedsforstyrrelser domineres dette system af forestillinger om dårlig mor, dårlig mig eller ikke-mig med det resultat, at selvet præges af meget 
begrænsede forestillinger om, hvordan det skal agere for at undgå angst og opretholde trygge relationer til andre og måske af, at dele af selvet endda dissocieres. Desuden beskriver Sullivan, hvordan mekanismen selektiv uopmcerksomhed kan medføre, at sådanne dominerende dårlige forestillinger om én selv og andre bliver selvforstærkende og søges bibeholdt, fordi meget veletablerede forestillinger skaber tryghed om end de er nok så negative (ibid 319).

2. Objektrelationsteorien grundlægges bl.a. hos Fairbairn, der tog udgangspunkt i at problematisere en stigende udbredelse af trangen til at gentage ulystbringende adfærd blandt patienterne i den kliniske praksis, som f.eks. gentagen opsøgen eller opretholdelse af lidelsesfulde relationer til andre. Freud havde haft vanskeligt ved at forklare sådan adfærd ud fra driftsteoriens hedonistiske idé om en grundlæggende lystorientering hos mennesket, hvorfor han havde lanceret den lidt svært anvendelige idé om dødsdriften. Fairbairns løsning på gentagelsesproblematikken tager ud fra systematiske refleksioner over erfaringer i den kliniske praksis afsæt i en omvendelse af driftsteorien, ifølge hvilken menneskets libidoenergi ikke er lystorienteret men rettet mod objekter (Fairbairn (2006), 137). I lighed med Sullivan anser Fairbairn nemlig mennesket som et grundlæggende socialt væsen, der i sin væren først og fremmest søger relationer med andre mennesker, og psykopatologi må i den forbindelse forstås ud fra konstitutive forstyrrelser i menneskets relationer. Allerede Freud havde i driftsteorien sådan set fremsat idéen om at ethvert individ søger objekter, men nu fremstilles altså idéen om at menneskets psyke fundamentalt set er social og interaktiv, og at vi som et udtryk for vores integrale og deltagende natur søger objektrelationer som et mål i sig selv og ikke som middel til at få tilfredsstillet underliggende behov (ibid 60). Libidoen er som objektsøgende princip en funktion af jeget, og i modsætning til Sullivan problematiserer Fairbairn altså subjektet ud fra termen jeg som i jegpsykologien, men tematiserer i overensstemmelse med Sullivan - og den øvrige psykoanalytiske tradition - individets udvikling i barndommen som central: I den tidligste udviklingsfase befinder barnet sig ifølge Fairbairn ikke som hos Freud i en primær narcissistisk fase, men i en infantil afhæengighedstilstand, hvor barnets jeg symbiotisk falder sammen med billedet af moren i en primær identifikation (ibid 145). Herefter etableres gradvist indre objektrelationer, forstået som barnets indre dannelse af relationer formet gennem samspilserfaringer med det ydre objekt, der er funderet i en klar differentiering af jeget og objektet. Barnet relaterer sig altså til forældrene gennem den kontakt de sørger for, og denne form for kontakt bliver mønster for den måde barnet fremover vil indgå i relationer til andre, uanset om kontakten er lidelsesfuld. En tilfredsstillende forældrekontakt vil medføre at barnet gradvist udvikler et voksent jeg nogenlunde svarende til Freuds endelige realjeg med en moden afhcengighed af relationer til andre mennesker i den omgivende verden og på udadvendt vis kan indgå i samfundslivet. Med denne betoning af objektrelationernes betydning for udviklingen kan Fairbairn, sammen med Sullivan, på sin vis vende tilbage til Freuds ætiologiske opfattelse fra forførelsesteorien (Køppe (1996), 546). Psykopatologi skyldes nemlig svære problemer i de tidlige objektrelationer, derved at barnet har savnet tilfredsstillende ydre objekter og som 
patologisk erstatning for de manglende virkelige relationer til sådanne derfor må vende sig fra den eksterne virkelighed og etablere relationer til indre internaliserede objekter præget af uklar differentiering mellem jeget og objektet. Nærmere bestemt vil de negative aspekter ved de afvisende ydre omsorgsobjekter blive fraspaltet og internaliseret som henholdsvis det indre afvisende objekt (den afvisende del forældrene) og det indre ophidsende objekt (den del af forældrene barnet længes efter) og det oprindelige jeg vil blive fraspaltet en antilibidinal og en libidinal jegdel, der knytter an til henholdsvis det afvisende og det ophidsende objekt. Gennem fraspaltningen og internaliseringen af deres negative aspekter som fantaserede indre tilstedeværelser af de utilfredsstillende forældre kan barnet skabe en indre og ellers umulig relation til de negative sider af forældrene samt en for sig selv helt uundværlig ydre relation til de ydre betydningsfulde objekter som gode omsorgspersoner og dermed altså opnå en vis grad af tryghed i forhold til dets omverden. Imidlertid vil den indre splittelse i jeget skabe konflikter og forhindre separationen og individuationen og dermed udviklingen af en moden afhængighed i relationen til andre mennesker, og barnet vil blive ved med at forme sine relationer efter det mønster som de tidlige internaliserede relationer repræsenterer. Som hos Sullivan er terapirelationens mål at skabe bevidsthed hos patienten om gentagelsen af disse negative relationsmønstre og en forståelse af, at vedkommende kan indgå i andre typer af relationer.

Hos Winnicott genfindes Sullivans og Fairbairns fremhævelse og videreudvikling af jegpsykologiens idé om, at kvaliteten af de tidlige relationer har betydning for barnets udvikling, og om hvorvidt det i den udvikler sig normalt eller psykopatologisk. For Winnicott sker denne teoridannelse på baggrund af systematiske refleksioner over observation af forbindelser mellem måden, hvorpå voksne mennesker i den kliniske praksis viser forstyrrelser i forhold til at opleve dem selv som et selv med en identitet og de forskellige måder, hvorpå mor-barn relationer finder sted i begyndelsen af livet. Winnicott benytter som i jegpsykologien begrebet jeg om den regulerende funktion af de psykiske mekanismer, mens han betegner subjektiviteten i oplevelsen af identitet med begrebet selv. Og, en normal udvikling, hvor individet som voksen har en solid oplevelse af at have et integreret og sandt selv med evne til at hævde sin individualitet og en følelsesmæssig modenhed til at hvile i sig selv og kunne være alene, kræver at det har dannet et godt indre objekt i barndommen, som det er i konstant kontakt med. Forudsætningen for en normal udvikling med etableringen af et sådant godt indre objekt er tilstedeværelsen af en tilstrcekkeligt god mor (den-almindeligt-hengivnemor-faktor), der kan respondere beskyttende, omsorgsfuldt og tilfredsstillende på det særlige barnets egenartede væremåde (Winnicott (2000), 21, 47). Denne primcre moderlige optagethed vil en psykisk og fysisk normalt fungerende mor almindeligvis udvikle fra slutningen af graviditeten og dermed kunne præstere en tilstrækkeligt god holding, håndtering og objektreprcesentation, som er Winnicotts betegnelse for morens 3 basale omsorgsfunktioner. Moderens udøvelse af holding fasciliterer spædbarnets jegorganisering fra et uintegreret stadium, hvor barnet og moren opleves som et symbiotisk eet i en primæridentifikation, til et integreret selv med en differentieret oplevelse af noget 
er ikke-MIG og at ”Jeg ER”(ibid 67). Samtidig understøttes integrationen mellem kroppen og psyken gennem håndteringen og integrationen mellem objektverdenen og barnets realisering gennem objektpræsentationen. Disse tilpasningsfunktioner i de første leveår er afgørende for at barnet kan udvikle sig fra en tilstand af absolut afhæengighed, hvor det oplever sig selv som omnipotent, til en tilstand af voksende uafhæengighed, hvor barnet erkender moderens selvstændige eksistens og gennem realitetsprincippet dermed sin egen almagt som illusorisk. Barnet har fra fødslen sin egen inderste personlighedskerne, det sande selv, der viser sig i dets helt særlige måde at relatere sig til omverdenen på . Er moren ikke en tilstrækkeligt god nok mor ved ikke at spejle eller tilpasse sig og beskytte barnets subjektivitet og hermed kunne rumme dets forskellige følelser, vil barnet udvikle et falsk selv som forsvar for det sande selv - et uintegreret selv, der afspejler morens utilstrækkelighed og er udtryk for barnets føjelighed over for andre menneskets forventninger og tilpasning til deres adfærd (Winnicott (1996), 188). Menneskets evne til stabil og moden erfaring af sin egen væren og til interpersonel realitetstestning udvikles altså i tidlige mellemmenneskelige relationer, og svigtes barnet i denne udvikling vil det have en dårlig evne til at erfare sig selv som et individ med en sammenhængende og kontinuerlig væren, lige som at dets oplevelse af andre vil være påvirket af projektioner.

3. Lige som Sullivan, Fairbairn og Winnicott lægger Bowlbys tilknytningsteori vægt på relationerne frem for drifterne som determinerende for personlighedsdannelsen, og viser hvordan kvaliteten af de tidlige relationer mellem barnet og de betydningsfulde omsorgspersoner og disses konkrete væremåder over for barnet påvirker arten af barnets selvopfattelse og nære relationer som voksen og kan forklare fremkomsten af psykopatologiske lidelser. Med Bowlby gøres det, som hos Sullivan, imidlertid helt klart, at der som i Freuds forførelsesteori er tale om konkrete relationer til andre mennesker og ikke ønskefantasier om seksuel tilfredsstillelse som i Freuds driftsteori, eller som i den tendens til at problematisere relationer til indre fantaserede objekter, vi så hos Fairbairn (Bowlby (2003), 112). Og, mens de andre omtalte relationsteorietikere havde været præget af en markant tendens til at nedtone problematiseringen af den menneskelige værens fysiologisk-biologiske dimensioner fra Freuds psykoanalyse, integrerer Bowlby modsat disse andre indsigter fra etologien og de kognitive videnskaber i hans refleksioner over observationer af især børns og deres mødres adfærd (ibid 11). Ifølge Bowlby besidder mennesket en række biologisk forankrede adfærdsformer, der som et instinktivt repertoire til en vis grad er forprogrammerede, og som i et sædvanligt miljø udvikles i løbet af de første levemåneder. Som hos dyrene gælder dette ved siden af seksuel adfærd og spiseadfærd især tilknytningsadfcerden, der livet igennem aktiveres som beskyttelse mod farer, når mennesket er bange eller under stor belastning (ibid 134). Mennesket er med andre ord forudprogrammeret til at udvikle sig socialt samarbejdende, og tilknytningsadfærden udvikles med begrundelse i en separationsangst, en angst for at blive forladt af tilknytningspersonen og dermed efterladt alene, hvilket er den ultimative risikofare for barnet. Mens tilknytningen repræsenterer 
barnets emotionelle oplevelse af tryghed, når tilknytningspersonen er til stede, repræsenterer forladtheden således barnets emotionelle oplevelse, når tilknytningspersonen er fraværende eller utilgængelig. Barnets tilknytningsadfærd aktiverer forældrenes komplementære instinktive omsorgsadfæerd, og den almindelige følsomme mor vil hurtigt indstille sig på at sætte sig ind i og afpasse sig barnets rytme og adfærd (ibid 17). At Bowlbys bog er skrevet i 1980’erne og således i en tid med radikalt forandrede kønsrollemønstre end i de andre teoretikeres samtid viser sig for øvrigt ved, at han tilkender faren en mulig ligeværdig rolle som tilknytningsfigur for sit barn (ibid 19). Uanset kønnet er forældrenes opgave at kunne forsyne barnet med en sikker base, hvorfra det kan vende sig ud i verden på egen hånd, og samtidig kan vende tilbage til, når det er ked af det eller bange (ibid 55). Gradvist vil barnets forventninger til forældrenes forventede adfærd internaliseres og blive en del af barnets personlighed som dets indre arbejdsmodeller (ibid 144). De indre repræsentationer som barnet har af dets relationer til betydningsfulde andre i dets omgivelser etableres således som betydningsfulde erfaringsmæssige og kognitive strukturer og får således en afgørende indflydelse på udviklingen af barnets selv. Disse indre arbejdsmodeller har en adaptiv funktion i forhold til perceptionen af virkeligheden og de fungerer som et skema barnet vil lægge ned over nye relationelle samspil i sit liv. Det betyder også, at kvaliteten af det tilknytningsmønster og de indre arbejdsmodeller et menneske udvikler afhænger af den måde, hvorpå moren - og faren - har behandlet det og været $\mathrm{i}$ stand til at drage omsorg og skabe en sikker base. En accepterende og omsorgsfuld tilknytningsfigur med en sikker base vil fremkalde et menneske med et positivt selvværd og med sikre tilknytningsmønstre og et mod på at træde ud i og til i livet, mens en afvisende og ukærlig tilknytningsfigur med en usikker base vil fremkalde et menneske med et negativt selvværd og med usikre og defensive tilknytningsmønstre.

\section{Femte fase: Selvpsykologien}

Freud brugte ikke begrebet selv men kun begrebet jeg, mens Sullivan brugte begrebet selv på en lidt udefineret måde, og Winnicott gjorde brug af selvbegrebet uden dog helt klart at adskille det fra jegbegrebet. Hos Kohot udvikles en egentlig selvpsykologi på grundlag af en systematisk problematisering af forhold ved narcissistiske personlighedsforstyrrelser af mindre sværhedsgrad med uspecifik vantrivsel og gennemgående tomhedsfølselse, der udgjorde en stadig større del af den psykoanalytiske praksis og ikke lod sig forklare tilstrækkeligt inden for den eksisterende teori: Et lidelsesmønster, der ifølge Lasch er udpræget i den senmoderne vestlige kultur og afspejler bagsiden ved nogle grundlæggende strukturer og mekanismer i vor tids levevis og sociale væren (Lasch (1983)). Ifølge Freuds jegpsykologi måtte menneskets psykiske normalitetsgrad forstås ud fra graden af, hvor godt det lykkes jeg'et at omforme drifternes energi fra det'et til realitetsorienterede og veltilpassede handle- og oplevelsesmåder. I den sammenhæng skulle den sekundære - og patologiske - narcissisme som allerede nævnt forstås derved, at i stedet for at der sker en overskridelse af den primære 
narcissistiske selvoptagethed med udviklingen af det modne objektrettede jeg geninvesteres libidoen i jeget som svar på objektfrustrationer. Kohuts tidlige selvpsykologi i begrcenset forstand arbejder i stort omfang videre med terminologien og modellerne fra Freuds jegpsykologi og tilføjer selvstrukturen som betegnelse for en kontinuert indre erfaring, der omfatter indholdet af driftsmæssigt ladede selvrepræsentationer i det psykiske apparat (Kohut (2000), 10). Denne driftsladning (narcissistisk libido) henviser til, at der udvikler sig en normal narcissisme normalt efter den primære fase, som ikke skal opgives til fordel for objektkærlighed. Ifølge Kohut etableres der på det tidligste narcissistiske udviklingstrin et arkaisk grandiost selv, der er drevet mod oplevelser af en slags omnipotens og befinder sig i en slags homeostatisk ligevægt. Skal barnet realisere et sundt selv fordrer det, at omsorgspersonerne reagerer på barnets behov og ønsker med en optimal frustration, hvormed dets fuldkommenhedsideal brister op andet udviklingstrin. Barnets psykiske struktur vil reagere på denne forstyrrelse ved parallelt at etablere to nye systemer, der skal være fuldkomne: (1) Barnet investerer en del af sin narcissistiske libido og dets arkaiske krav i det grandiose selv, der betegner et integreret kropsselv drevet af barnets ambitioner; (2) resten investeres i barnets omsorgspersoner, hvormed det idealiserede forceldreimago etableres som fuldkommengjort selvobjekt drevet af barnets idealer - modsat objektrelationer tilhører selvobjektet på sin vis den ydre verden men er helt afhængigt af den intrapsykiske oplevelse (ibid 31). På det tredje udviklingstrin brister disse to systemer, dels ved at det grandiose selv afsløres som uvirkeligt og mere modererede elementer indbygges i ambitionerne hos det reale modne selv, der besidder en grundlæggende tillid til at være værdifuldt og kunne forstås af andre. Dels svigter forældrene i forhold til forventningerne om fuldkommenhed, hvorfor der forudsat psykisk modenhed sker en gradvis omformende internalisering og depersonalisering af aspekter ved objektimagoet som nu bliver funktioner den indre struktur selv udfører (ibid 50). Mislykkes transformationerne af den arkaiske narcissisme og dens krav ikke på grund af forstyrrelser i forholdet til det idealiserede objekt vil selvet have svigtende funktioner udtrykt ved diffus narcisistisk sårbarhed, reseksualisering af konflikter eller opsøgen af ydre ideelle skikkelser.

I Kohuts senere selvpsykologi $i$ udvidet forstand skabes mere distance til jegpsykologiens teoriapparat, og selvet opfattes nu som den centrale psykiske instans og ikke bare et indhold i psyken - den centrale psykodynamik udgår altså hverken fra drifter eller jegfunktioner men måden, hvorpå vi gennem vores fornemmelse for os selv organiserer vores psyke og væremåde. Dette selv er så lige præcist ikke bare et indre anliggende men angår som måden, hvorpå vi relaterer os til andre mennesker og vores kultur. Samtidig udvikles og formes det rudimentære selv i barnets tidlige interaktioner med dets centrale selvobjekter, der fra begyndelsen forholder sig til barnet, som om det allerede har et selv, og som vil reagere empatisk på nogle bestemte potentialer hos barnet (Kohut (2001), 79). Selvet er således relationelt formet og kerneselvet, som oplevelsen af at være et uafhængigt og integreret selv, er ifølge Kohut organiseret som centrum for to poler svarende til en udvikling af den tidlige selvpsykologi: En spejlingspol for det grandiose- ekshibitionistiske selv, der er grundlaget 
for selvbilledet og via empatisk spejling fra selvobjekterne under sunde forhold omdannes til realistiske ambitioner; og en idealiseringspol for det idealiserede forældrebillede, der er grundlaget for individets evne til at etablere idealer og nære og stabile forhold til andre mennesker (ibid 135). Hermed er selvet i sin dynamik karakteriseret ved to måder at relatere sig til sine omgivelser på, nemlig dels som de selvudtryk, hvormed individet skaber indtryk hos andre og derved spejler sig i deres reaktioner, og dels som de relationer til andre og kulturværdier, hvormed individet giver sig selv en oplevelse af at have meningsfulde mål med sit liv. Således har relationer til andre mennesker en meget afgørende funktion for selvets udvikling og væremåde, og i overensstemmelse med den psykoanalytiske tradition gør Kohut relationen til forældrene og eventuelle andre centrale omsorgspersoner centrale for senere livsomstændigheder. For mennesket kræver udviklingen af et stabilt kerneselv, at det barndommen understøttes af tilstrækkeligt gode selvobjekterfaringer i forhold til spejling og idealisering - altså at omsorgspersonernes evne til at levere en empatisk intersubjektiv relation er determinerende for barnets evne til at integrere de to poler i kerneselvet og opnå en sund narcissisme. Og, Kohut angiver uddybende, hvordan ethvert menneske i sin udvikling har behov for at opleve: (1) at det kan identificere sig med en ligestillet anden; (2) at det kan smelte sammen med en idealiseret anden; og (3) at det kan blive spejlet af en bekræftende og empatisk anden. Omvendt vil svigt fra selvobjekterne gennem mangelfuld eller fraværende spejling eller traumatisk skuffelse over deres evner som idealer medføre dannelsen af et mangelfuldt eller infantilt selv. Modsat Freuds klassiske psykoanalyse fokuserede på evnen til en hensigtsmæssig regulering af de indre kropslige drifter, henviser den sene Kohuts selvpsykologi til selvets dannelse i sammenhæng med grundlæggende dynamikker som evnen til rettethed mod det idealiserende og spejlende samt påvirkning fra og tilknytning til selvobjekterne og kulturværdierne. Selv om Kohut lige som Winnicott, Fairbairn, Bowlby og Sullivan henviser til, at mennesket har et "indre anliggende”, peger han lige som disse på et kronisk traumatiserende interpersonelt miljø i barndommen som årsag til psykiske lidelser, og viser hvordan selvets udvikling ikke blot er en indefrakommende genese men endnu mere et spørgsmål om relationer til andre.

\section{Fase 6: Den relationelle psykoanalyse}

Skal man pege på en sjette fase i psykoanalysens historie kan det enten være affektteorien hos Tomkins eller den relationelle psykoanalyse, der fra 1980'erne formuleres hos Mitchell og andre. Her skal sidstnævnte skitseres, om end der lige så meget som en ny fase er tale om et forsøg på at eksplicitere, integrere og videreudvikle relationsaspektet hos især Sullivan, Fairbairn, Winnicott, Bowlby og andre. Ifølge Mitchell sker dette fordi, at problemerne i vores nuværende livsverden skyldes forstyrrelser i de mellemmenneskelige relationer og for derfor at kunne præsentere en praktisk anvendelig integrativ relationel psykoanalyse, der både indeholder et eksplicit alternativ til uansvarlige relativisme i den radikale socialkonstruktivisme og til den anakronistiske objektivisme i 
jegpsykologiens drift-forsvarteori (Mitchell (1998), 9; (1999), xvi). Ifølge Mitchell er relations- og driftsmodeller for det første uforenelige, og han afviser derfor Kohuts forsøg på at integrere dem på en afbalanceret måde. For det andet betragte han helt afgørende relationer og ikke drifter som grundlæggende for menneskets psykiske liv og beskriver, hvordan vi udvikler os og virker som et selv i en relationel matrix med andre (Mitchell (1988), 3). Menneskets udvikling er fra begyndelsen en udfoldelse af dets basale sociale natur i denne relationelle matrix, og som relationelt kan selvet ikke forstås som adskilt fra de andre. Det betyder ikke, at det intrapsykiske ikke tilkendes nogen eksistens, men da psyken fundamentalt set er interaktiv, må dette indre forstås som afledet af det interaktionelle felt (ibid 61; (2003), 57). Ifølge Mitchel må en relationel psykoanalyse baseres på et multidimensionel syn på disse interaktioner, hvorfor han beskriver, hvordan de finder sted inden for et hierarki af stadig mere komplicerede relationsformer: (1) Ikke reflektiv adfærd; (2) Affektiv gennemtrængelighed; (3) Selv-andre konfigurationer og (4) Intersubjektivitet (ibid 59-66). Samtidig gør han gældende, at psykiske lidelser udspringer fra konflikter i de mellemmenneskelige relationer, der internaliseres i den tidlige udvikling og reaktualiseres i voksenlivet. Men Mitchell vender sig også imod infantilismen som betegnelse for den tendens, vi hidtil har set i psykoanalysen, til at drage en parallel mellem disse lidelser mangelfulde omsorgsrelationer i første leveår (Mitchell (1988), 146). Skaderne er interaktive, relationelle produkter som med "det indre barn" vil udtrykke sig i fremtidig erfaring, men psykopatologien afspejler ikke tidspunktet for svigtet men den grad og intensitet hvormed det har præget barnet et eller andet sted i dets udvikling fra spæd til voksen. Og sådan ser konturerne af den almenpsykologiske dimension i en del af den relationelle psykoanalyse ud, der måske glimrer ved at være mere af et teoretisk projekt end et projekt, som udspringer fra problematiseringen af nogle uforklarlige forhold i den kliniske praksis. Dette gælder dog ikke den relationelle psykoanalyse som terapi, hvor det afsluttende skal bemærkes, at Mitchell i lighed med andre samtidige terapeuter gør meget ud af at undersøge det relationelle aspekt i den terapeutiske relation og fremhæver to-person aspektet heri: Både patient og analytiker er farvet af en subjektivitet, der vil påvirke terapien (Mitchell (2003), ch 4). Modsat den klassiske psykoanalyse hos Freud er det pastorale segment altså nedtonet til fordel for en betoning af, at terapeuten ikke besidder nogen objektivitet.

\section{Afslutning og perspektivering}

Dette projekt har fulgt problematiseringen af det relationelle aspekt i psykoanalysens udvikling gennem udvalgte nedslag i teorien. Det er beskrevet, hvordan relationer får en stadig mere udpræget betydning på baggrund af forskelligartede problematiseringer af nogle ændringer i symptombilledet i den kliniske praksis og et omfattende opgør med teoribygningen i den klassiske psykoanalyse. Om end anes det også, at lige netop psykoanalysen er tungt præget af sin arv fra traditionen fra urfaderen Freud og derfor måske lige så meget er teoretisk idealistisk som materialistisk i sin refleksive 
bevægelse gennem det klinisk-empiriske landskab. Godt nok forsøger Mitchell og andre gennem etableringen af den såkaldte relationelle psykoanalyse at slippe tøjlerne fra Freud, og det synes at virkelige hændelser og relationer i det faktiske liv får mulighed for en privilligering over elementer i fantasien. Men, den nye ”teori” er stadig så båret af overleverede begreber og modeller og så svagt empirisk funderet i konkret videnskabelig refleksion, at den ikke kan siges at rumme en reel ny orientering af psykoanalysen. Konsekvenserne er dog klare i forhold til, at man åbner for en opfattelse af mennesket som formet i sine relationer til andre, hvilket er mere adækvat i forhold til en forståelse af tilværelsen i den senmoderne virkelighed. En mere analytisk vidtrækkende udgave af en forståelse af det relationelle selv kunne dog passende indtegrere andre fagpsykologiske perskektiver på det relationelle aspekt. Det gælder blandt andet den stigende inddragelse af relationer i forståelsen af selvet, der findes i den britiske eksistensanalyse hos f.eks. Deurzen. Den eksistenspsykologiske tradition har gennem sin ambition om at etablere psykologien som en rent idiografisk videnskab fra begyndelsen været meget lidt optaget af de indre biologisk funderede sider af den menneskelige væren til fordel for en filosofisk inspireret betoning af menneskets eksistens frem for det essens - det er måden, hvorpå mennesket er til i verden, der er afgørende for, hvem det er og ikke omvendt: ”Mennesket er ikke andet, end hvad det gør sig selv til” (Sartre (1997),47). Selv om allerede Binswanger påpegede at mennesket er karakteriseret ved en væren-i-verden med sig selv (Eigenwelt), de andre (Mitwelt) og tingene (Umwelt) og dermed underforstod en relationel opfattelse af mennesket, har eksistenspsykologien dog haft en tendens til at betone den første individualistiske position i forlængelse af Kierkegaard tematisering af selvet som et selv, der forholder sig til sig selv (Kierkegaard (1963), 73). I de senere år er en art relationel vending imidlertid begyndt at melde sig i eksistenspsykologien og det er som nævnt bl.a. sket hos Deurzen, der betoner at selvet er et forhold, der som en grundlæggende væren-verden forholder sig til (1) sin egen krop og tingene i den fysiske dimension af sin verden; (2) andre mennesker i den sociale dimension; (3) sin egen angst, autenticitet og frihed i den personlige dimension og (4) værdier og overbevisninger i den spirituelle dimension. Samtidig betoner Deurzen, i lighed med at Mitchell beskriver den intrapsykiske eksistens som afledet af den interpsykiske, at selvets formes af relationerne i disse dimensioner og at dets personlige forhold til sig selv i et væsentligt omfang er afledet af dets relationer i de andre dimensioner (Deurzen (2002)). Endelig skal det kort bemærkes, at også dele af den sociologisk udsprungne socialkonstruktionistiske psykologi problematiserer relationer ud fra et fokus mod konstruktionen af identitet og subjektivitet i hverdagsdiskurserne i den mellemmenneskelige interaktion (Burr (2003), 23). Med andre ord undersøges menneskers samtaler som udtryk for en verden, der skabes i den sociale interaktion, og deres identitet og subjektivitet konstrueres gennem positionering inden for diverse diskurser. Da vi alle indskriver os i forskellige og ofte modsætningsfyldte diskurser, som vi bruger aktivt som ressourcer, konstrueres vores identiteter og subjektpositioner også gennem forskellige diskursive ressourcer, og identiteten er derfor fragmenteret, multipel og relationel. Vores såkaldte psykologiske 
egenskaber såsom vores personlighed henviser derfor ikke til stabile indre fænomener e.l. men er kun tilstede i diskurser som effekter af sproget, og idet forskellige diskurser giver mening til forskellige aspekter af vores liv kan en person beskrives ved hjælp af alle de positioner vedkommende indtager inden for diskursive sammenhænge. Af samme grund skal følelser, tanker og lignende ikke problematiseres som interne strukturer bag menneskers sproglige udtryk, men gennem den måde, de fungerer på for folk som intentionel social adfærd i interaktion med andre ud fra antagelse om at mennesker er aktører i en social sfære (Burr (2003), 131). Som alternativ til personlighedsbegrebet taler Gergen om, at mennesket må opfattes som et relationelt selv, og vi benytter narrativer til at konstruere og strukturere vores erfaringer af os selv i de mange forskellige relationer, vi indgår i, til en oplevelse af sammenhængende identitet over tid (Gergen (1997), 195). Den konstruktivisme, som socialkonstruktionismen involverer er dog væsensforskellig fra den videnskabelige refleksion over den kliniske praksis, der findes i psykoanalysen og eksistenspsykologien, og på mange måder er det meget forskellige opfattelser af det relationelle selv, der fremkommer.

\section{Litteratur}

Ayer, A. (1990): Sprog, sandhed og logik. Kbh.: Det lille Forlag

Bertelsen, P. (2005): Personlighedspsykologi. Kbh.: Frydenlund

Burr, V. (2003): Social Constructionism. London: Routledge

Binswanger, L. (2004): The existential analysis of thought. In May (ed): Existence. US: Aronson

Bowlby, J. (2006). En sikker base. Kbh.: Hans Reitzels Forlag

Christensen, G. (2005): Psykologiens videnskabsteori. Roskilde: Roskilde Universitetsforlag

Deurzen, E (2002): Predictable difficulties In Svare (ed) Philosophy in Society. Oslo: Unipubforlag

Fairbairn, W. (2006 [1952]): Psychoanalytic Studies of the Personality. London: Routledge

Foucault, M. (1992a): The Use of Pleasure. London: Penguin

Foucault, M. (1992b): The Care of the Self. London: Penguin

Foucault, M. (1994): Viljen til viden. Kbh.: Det lille Forlag

Foucault, M. (1999): Ordene og tingene. Kbh.: Spektrum

Freud. A. (1984a [1936]): Jeg'et og forsvarsmekanismerne. Kbh.: Hans Reitzel

Freud, A. (1984b [1965]): Normalitet og patologi i barndommen. Kbh: Hans Reitzel

Freud, S. (1974 [1911-5]): Metapsykologi I. Kbh.: Hans Reitzel

Freud, S. (1975 [1948]): Kulturens byrde. Kbh.: Hans Reitzel

Freud, S. (1976 [1920-5]): Metapsykologi 2. Kbh.: Hans Reitzel

Freud, S. (1980 [1895]): Udkast til en videnskabelig psykologi. Kbh.: Hans Reitzel

Freud, S. (1998 [1941]): Psykoanalysen i grundtrcek. Kbh.: Det lille Forlag

Freud, S. \& J. Breuer (2004 [1895]): Studies in Hysteria. London: Penguin

Gergen, K. (1997): Virkelighed og relationer. Kbh.: DPF

Jørgensen, C.R. (2002): Psykologien i senmoderniteten. Kbh.: Hans Reitzels Forlag

Jørgensen, C.R. (2006): Personlighedsforstyrrelser. Kbh.: Akademisk Forlag

Kierkegaard, S. (1963): Samlede verker, bind 15. Kbh.: Gyldendal

Kohut, H. (2000 [1971]): Analysen af selvet. Kbh.: Det lille Forlag

Kohut, H. (2001 [1977]): Selvets psykologi. Kbh.: Det lille Forlag

Køppe S. \& O. Olsen (1996): Psykoanalysen efter Freud 1-2. Kbh.: Gyldendal

Køppe S. \& O. Olsen (1997): Freuds psykoanalyse. Kbh.: Gyldendal

Lasch, C. (1983): Narcissismens kultur. Kbh.: Gyldendal

Madsen, K.B. (1986): Psykologiens historie indtil 1945. Kbh.: Gyldendal

Martin, R. \& J. Baressi (2006): The Rise and Fall of Soul and Self. NY: Columbia U.P.

Mitchell, S. (1988): Relational Concepts in Psychoanalysis. London: Harvard University Press 
Mitchell, S. (1995): Freud and Beyond. US: Basic Books

Mitchell, S. (1998): The Analyst's Knowledge and Authority. In Psychoanalytic Quarterly: 67; 1-31

Mitchell, S. (ed)(1999): Relational Psychoanalysis - the Emergence of a Tradition: NY: Analytic Press

Mitchell, S. (2003): Relationality. London: Analytic Press

Perlman, D. (2006): The Cambridge Handbook of Personal Relationships. Cambridge: CUP

Porter, R. (red.)(1997): Rewriting the Self. London: Routledge

Quinodoz, J-M (2004): Reading Freud. Routledge: London

Ritchie, T. (red)(2005): Relationer i psykologien. Kbh.: Billesø og Balzer

Rose, N. (1998): Inventing our Selves. Psychology, Power and Personhood. London: Cambridge U.P.

Sartre, J-P.(1997): Eksistentialisme er en humanisme. Kbh.: Hans Reitzels Forlag

Saugstad, P. (1998): Psykologiens historie - en indføring i moderne psykologi. Oslo: Gyldendal

Sullivan, H. (1997 [1953]): The Interpersonal Theory of Psychiatry. New York: Norton

Sørensen, A. \& H.J. Thomsen (red) (2005): Det svcere liv - om lidelsen i den moderne kultur. Aarhus: AUP

Winnicott, D. (1996): Familien og den individuelle udvikling. Kbh.: Hans Reitzels Forlag

Winnicott, D. (2000): Spcedbørn og deres mødre. Kbh.: Hans Reitzels Forlag 